\title{
THE FACTORS AFFECTING BANK PROFITABILITY: THE CASE OF BOSNIA AND HERZEGOVINA
}

\author{
Almir Alihodžić \\ University of Zenica, Zenica, Bosnia and Herzegovina \\ e-mail: almir.dr2@gmail.com
}

ORCID: 0000-0001-9713-4651

(C) 2020 Almir Alihodžić

This work is licensed under the Creative Commons Attribution-ShareAlike 4.0 International License. To view a copy of this license, visit http://creativecommons.org/licenses/by-sa/4.0/

Quote as: Alihodžić, A. (2020). The factors affecting bank profitability: The case of Bosnia and Herzegovina. Financial Sciences, 25(2-3).

DOI: 10.15611/fins.2020.2.01

JEL Classification: G20, G21, G29

\begin{abstract}
This research includes all banks in Bosnia and Herzegovina $(\mathrm{B} \& \mathrm{H})$ and testing internal and external variables on bank profitability indicators. The primary goal of this paper is to determine, through correlation and regression analysis, the strength and significance of the external and internal variables on bank profitability in Bosnia and Herzegovina. Likewise, data were collected from quarterly reports of the Banking Agency of the Federation of B\&H and the Banking Agency of the Republika Srpska for the period 2008 Q1 to 2019 Q4. The following dependent variables were used: ROA, ROE and independent variables: GRNGL, GRNPL, GRGDP, concentration ratio of loans of the largest banks in the system (CR Loans), concentration ratio of deposits of the largest banks in the system (CR Deposits), CAR and loan-to-deposit ratio. The study found that there is a significant statistical impact of the variables on ROA and ROE. In addition, this study points out the need for banks to properly select debtors, and control costs, toxic loans and provisions in order to increase profits and reduce costs.
\end{abstract}

Keywords: profitability indicators, non-performing loans, concentration ratio, loan-to-deposit ratio.

\section{Introduction}

Generally, the approach to measuring the performance of banks is no different from the approach adopted in measuring the performance of companies.The profitability of banks in $\mathrm{B} \& \mathrm{H}$ is also influenced by the financial result of operations, which is determined by price and interest rate risk. Mostly it is a model of return on equity where decomposition is carried out in order to identify the sources that influenced the profitability of the company. The behaviour of company stock prices is the best indicator of the success of their business. However, with banks the return on equity is often not a reliable indicator because usually small and medium-sized banks are not 
listed on any of the stock exchanges. In this regard, the use of different profitability indicators is the logical choice. Therefore for banks whose stock is listed on stock exchanges, which is often the case in countries with underdeveloped capital markets, using profitability ratios is the only way to measure their business performance (Đukić, 2011, p. 185). Profitability indicators provide a systematic summary of the significance of information based on the vast amount of data contained in the financial statements. Financial managers use ratios to evaluate their company's performance against competitors and set goals for future business.

Both ROE and ROA are very significant indicators of profitability, however more researchers are focusing on ROE as it shows the profitability of the bank from the point of view of capital investment, and is therefore more important in the context of bank shareholders (Mishkin, 2007). In this paper both ROE and ROA are used as dependent variables. In the financial system of Bosnia and Herzegovina, banks have the most dominant share in the structure of the total system whose participation in 2018 amounted to $88.5 \%$. The profitability of the banking sector remained at a high level, where ROE and ROA had slightly lower values than the previous year. Banks in Bosnia and Herzegovina derive most of their income from loans, where about $60 \%$ of the total relate to loans (The Central Bank of Bosnia and Herzegovina, 2018).

The first analysed indicator is return on equity (ROE), following an identical pattern in moving to higher values. The negative ROE of banks in Bosnia and Herzegovina in 2010 was a direct result of increased costs and increased deductions from current revenues to cover loan losses. After 2010, profits were positive and reach the level of $10 \%$. The highest levels of earnings were recorded in the third quarter of $2018(19.90 \%)$ and the fourth quarter of 2018 (20.40\%) respectively. The retention of expansionary monetary policy and low-interest rates by the ECB had positive implications for boosting economic growth not only in EU countries but also in Southeast Europe (Banking Agency of the Federation Bosnia and Herzegovina, 2018, p. 38). The zero hypothesis supports the random-effects model. The second analysed indicator of banks in Bosnia and Herzegovina return on assets (ROA) which had a volatile trend with a decline in value in 2010 as a result of the increased costs of loan loss provisions and poor quality of the loan portfolio. Later on, due to the recovery of economic activity and falling interest rates and write-offs of toxic loans, the ROA was increased slightly to $1 \%$ in the last quarter of 2016 . In the fourth quarter of 2018 , the ROA was $1.2 \%$, and the average value of the observed period was about $0.48 \%$.

As one can see from the above figure, the liquidity indicator of bank loans in Bosnia and Herzegovina (i.e. loan-to-deposit ratio) had a very variable trend. At the end of the fourth quarter of 2008, the amount of credit placements was almost equal to the amount of total bank deposits in banks of Bosnia and Herzegovina, which means that only one year after the crisis, banks reduced risk aversion and increased lending activity. However, immediately after 2008 there was a turnaround in their credit policies, where the loan-to-deposit ratio in 2009 amounted to $88.69 \%$, or total 


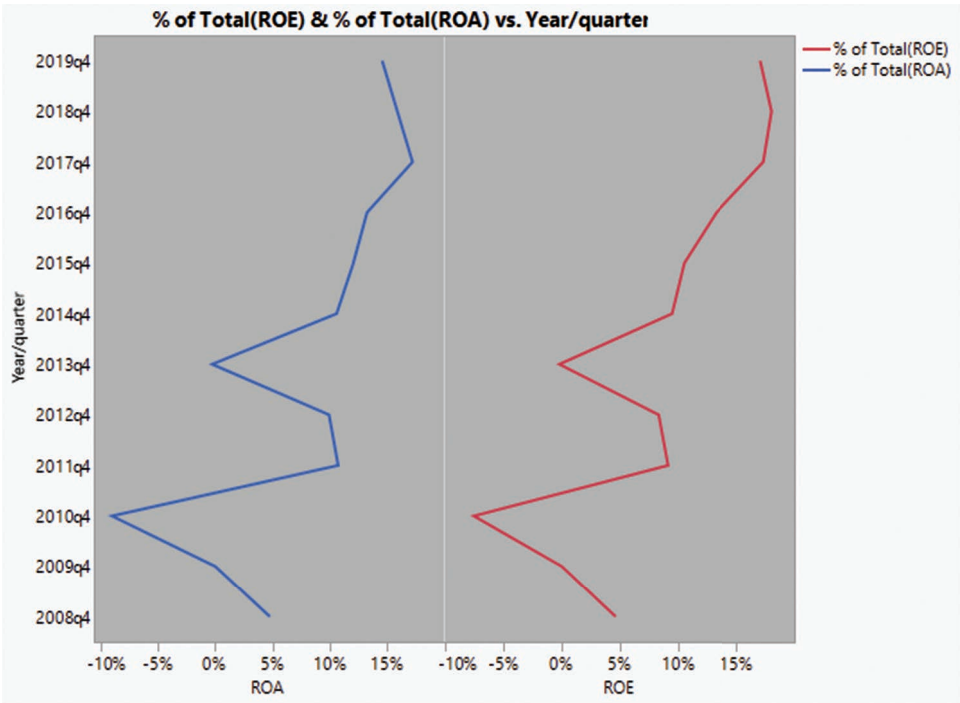

Fig. 1. Trend of return on equity (ROE) and return on assets (ROA) of banks in Bosnia and Herzegovina in the period 2008q4-2019q4 (in \%)

Source: author's study based on data from the Banking Agency of the Federation of Bosnia and Herzegovina and the Banking Agency of Republika Srpska.

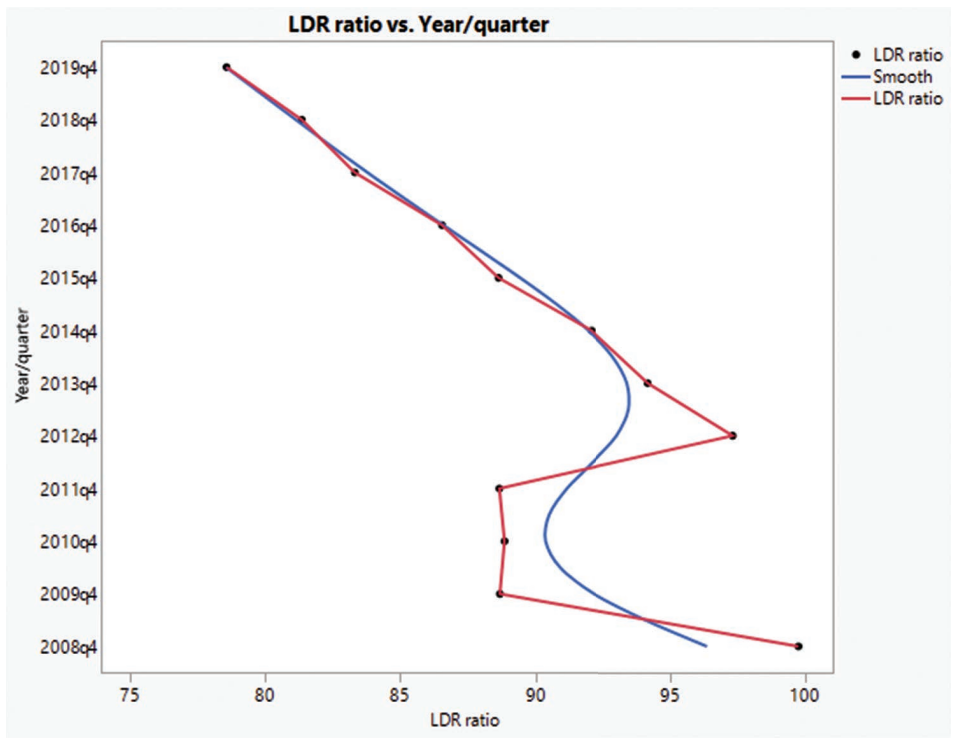

Fig. 2. Trend of the loan-to-deposit ratio of banks in Bosnia and Herzegovina in the period 2008q1-2019q4

Source: author's study based on data from the Banking Agency of the Federation of Bosnia and Herzegovina and the Banking Agency of Republika Srpska. 
deposits were higher by $11.31 \%$. This is primarily the result of the banks prudence resulting from the impact of the global economic crisis, weakened economic activity, increased credit risk and other factors. That prudence and the reduced volume of lending activity of banks in Bosnia and Herzegovina lasted until 2012 when there was a slight recovery period of economic activity, where banks slightly increased the amount of credit placements as reflected in the credit liquidity indicator, which in 2012 amounted to $97.31 \%$. Almost equal levels between total loans and deposits were recorded only in 2008 and 2012. The amount of deposits in relation to loans from 2016 to 2019 tended to increase as a result of the absence of alternative forms of savings and the establishment of a deposit insurance system. Even after the crisis, banks continued to pursue a policy of rationalization of loans due to the continued high credit risk, which is the basis of financial stability and the inability to find good debtors. The primary goal of this paper is to attempt to identify and recognise the factors affecting the profitability of banks operating in Bosnia and Herzegovina. Therefore, this research focuses on the determinants of banking sector profitability that can be divided into two groups, namely internal and external factors (Gul, Irshad, and Zaman, 2011). The paper consists of four sections. The first describes the importance of profitability indicators in measuring the efficiency of B\&H banks' operations, as well as internal and external variables that affect profitability indicators such as ROA and ROE. The second section provides an overview of empirical evidence in terms of the results of the influence of internal and external factors on the profitability of bank operations. Section 3 describes the chosen research methodology, and finally Section 4 deals with the data necessary for the analysis and the results of the research with recommendations.

\section{Empirical evidence and research hypotheses}

Goddard, Molyneux, and Wilson (2004) used panel analysis as well as cross-sectional regression to estimate growth and profitability models in a sample of nearly 600 banks from five European Union countries for the period 1992 to 1998. According to Boubakri, Cosset, Fischer, and Guedhami (2005), bank privatization to strategic investors plays a significant role in business performance. The authors found that newly privatized banks controlled by local industry groups became more exposed to credit and interest rate risk after privatization. On the other hand, privatized banks controlled by foreign investors have become more cost-effective. In many transition countries, control of a large number of privatized banks has shifted from state ownership to foreign ownership. The entry of foreign banks after privatization had a positive impact on the way that domestic banks became much more efficient in terms of overhead costs and interest spread, although it did not always have a positive effect on profitability.

Kosmidou (2008) investigated the factors influencing the operations of Greek commercial banks in the period 1990-2002, and came to the conclusion that 
profitability is positively correlated with well-capitalized banks and a lower cost-income ratio, and that the growth of GDP is positively related to the profitability of banks, while the inflation rate is negatively related to the profitability of banks. The results of the Bordeleau and Graham study (2010) suggested that large amounts of liquid assets are not held by banks because they reduce profitability, which means that maintaining liquidity is important, but only to a certain extent, i.e. not too much and not too little.

Naceur and Omran (2011) investigated the impact of the concentration, bank regulation, institutional and financial development on the margins and profitability of Middle Eastern and North African banks. They came to the conclusion that credit risk and capitalization have a significant impact on the profitability and economy of banks. They also stated that there was no significant impact of macroeconomic and financial development indicators on the level of net interest margins, except for inflation. Likewise, they found that institutional and regulatory variables have a significant impact on the bank's operations. Ćuraka, Poposkib, and Pepura (2012) investigated the bank-level, industry-level and macroeconomic factors that may affect the profitability of the Macedonian banking sector, using a dynamic panel consisting of 16 banks between 2005 and 2010. They concluded that the operating cost is a major determinant of bank profitability, and that solvency and liquidity risks have an impact on profitability. The findings also indicated that the concentration, the banking system reform and economic growth have a significant impact on bank profitability.

According to a study by Borio, Gambacorta, and Hofmann (2015), high short-term interest rates can have the effect of reducing bank's profitability. The results of their research show that the effects of short-term interest rates on bank profitability depend on the elasticity of supply and demand for loans. In conditions where the demand for loans is resilient, and when interest rates on deposits are higher, this may have the effect of reducing bank's profitability. According to the results of the study by Căpraru and Ihnatov (2015), bank profitability is negatively affected by the cost/income ratio, bank size, credit risk and market concentration. Ibrahimov (2016) analysed the impact of banking and macroeconomic variables on the profitability of 41 banks for the period 2012-2015. Based on the results of the statistical panel, he found that bank size and bank capital have a positive impact on the return on assets, while liquidity risk is negatively associated with the return on assets. In the context of macroeconomic variables such as the devaluation of the exchange rate and the price of oil, he concluded that they both have a positive and a negative impact on profitability.

Satria, Supriyadi, Irfani, and Djamil (2018) conducted a survey on a sample of the 10 largest commercial banks in ASEAN over the period 2012 to 2016. They found that equity to asset ratio had a positive impact on profitability, while the following factors had a negative impact on profitability, namely loan to deposit, investment to asset and GDP. 
To study the impact of factors on the profitability of banks in Bosnia and Herzegovina as measured by return on assets (ROA) and return on equity (ROE), the following hypotheses were built. Based on the goal set in the introductory part of the paper, these hypotheses were tested:

\section{First hypothesis}

$\mathrm{H}_{0} \mathrm{I}$ ): There is no significant statistical impact of the factors (the growth rate of net gross/loss - GRNGL, the growth rate of non-performing loans - GRNPL, GDP growth rate - GRGDP, concentration ratio of loans of the largest banks in the system - CR Loans, concentration ratio of deposits of the largest banks in the system - CR Deposits, capital adequacy ratio - CAR and loan-to-deposit ratio) on the return on assets at $\mathrm{p} \leq 0.05$. This consists in the following sub-hypotheses:

$\mathrm{H}_{0} \mathrm{I}-1-$ There is no significant statistical impact of the growth rate of net gross/ loss on the return on assets (ROA) at $p \leq 0.05$.

$\mathrm{H}_{0} \mathrm{I}-2$ - There is no significant statistical impact of growth rate of non-performing loans on the return on assets (ROA) at $p \leq 0.05$.

$\mathrm{H}_{0} \mathrm{I}-3$ - There is no significant statistical impact of growth rate of GDP growth rate on the return on assets (ROA) at $p \leq 0.05$.

$\mathrm{H}_{0} \mathrm{I}-4-$ There is no significant statistical impact of concentration ratio of loans of the largest banks in the system on the return on assets (ROA) at $p \leq 0.05$.

$\mathrm{H}_{0} \mathrm{I}-5-$ There is no significant statistical impact of concentration ratio of deposits of the largest banks in the system on the return on assets (ROA) at $p \leq 0.05$.

$\mathrm{H}_{0} \mathrm{I}-6$ - There is no significant statistical impact of capital adequacy ratio on the return on assets (ROA) at $p \leq 0.05$.

$\mathrm{H}_{0} \mathrm{I}-7$ - There is no significant statistical impact of loans to deposit ratio on the return on assets (ROA) at $p \leq 0.05$.

\section{Second hypothesis}

$\mathrm{H}_{0} \mathrm{II}$ ): There is no significant statistical impact of the factors (the growth rate of net gross/loss - GRNGL, the growth rate of non-performing loans - GRNPL, GDP growth rate-GRGDP, concentration ratio of loans of the largest banks in the system - CR Loans, concentration ratio of deposits of the largest banks in the system - CR Deposits, capital adequacy ratio - CAR and loan-to-deposit ratio) on the return on equity at $p \leq 0.05$. This consists in the following sub-hypotheses:

$\mathrm{H}_{0} \mathrm{II}-1$ - There is no significant statistical impact of the growth rate of net gross/ loss on the return on equity (ROE) at $p \leq 0.05$.

$\mathrm{H}_{0} \mathrm{II}-2-$ There is no significant statistical impact of growth rate of non-performing loans on the return on equity (ROE) at $p \leq 0.05$.

$\mathrm{H}_{0} \mathrm{II}-3$ - There is no significant statistical impact of growth rate of GDP growth rate on the return on equity (ROE) at $p 0.05$. 
$\mathrm{H}_{0} \mathrm{II}-4$ - There is no significant statistical impact of concentration ratio of loans of the largest banks in the system on the return on equity (ROE) at $p \leq 0.05$.

$\mathrm{H}_{0} \mathrm{II}-5-$ There is no significant statistical impact of concentration ratio of deposits of the largest banks in the system on the return on equity (ROE) at $p \leq 0.05$.

$\mathrm{H}_{0} \mathrm{II}-6-$ There is no significant statistical impact of capital adequacy ratio on the return on equity (ROE) at $p \leq 0.05$.

$\mathrm{H}_{0} \mathrm{II}-7$ - There is no significant statistical impact of loans to deposit ratio on the return on equity (ROE) at $p \leq 0.05$.

\section{Empirical methodology and data}

The author attempted to answer the following question: Which of the independent variables in the model has the most substantial impact on the bank profitability of Bosnia and Herzegovina on the one hand, and the other hand, which of the variables has the lowest impact? Based on the above mentioned research, the study investigated the aggregate effect of bank profitability in Bosnia and Herzegovina using the following regression model:

$$
\begin{gathered}
R_{0 A_{i, t}=\alpha+} \alpha_{1} G R N G L_{i, t}+\alpha_{2} G R N P L_{i, t}+\alpha_{3} G R G D P_{i, t}+\alpha_{4} C R \text { Loans }_{i, t}+ \\
\alpha_{5} \text { CR Deposits }_{i, t}+\alpha_{6} \text { CAR }_{i, t}+\alpha_{7} L D R_{i, t}+\varepsilon_{i, t}
\end{gathered}
$$

and

$$
\begin{gathered}
R O E_{i, t}=\alpha+\alpha_{1} G R N G L_{i, t}+\alpha_{2} G R N P L_{i, t}+\alpha_{3} G R G D P_{i, t}+\alpha_{4} C R \text { Loans }_{i, t}+ \\
\alpha_{5} \text { CR Deposits }_{i, t}+\alpha_{6} C A R_{i, t}+\alpha_{7} L D R_{i, t}+\varepsilon_{i, t}
\end{gathered}
$$

where: $G R P L$ - the growth rate of profit/loss, GRGDP - the growth rate of non-performing loans, GRGDP - GDP growth rate, $C R$ Loans - concentration ratio of loans of the largest bank in the system, $C R$ Deposits - concentration ratio of deposits of the largest banks in the system, $C A R$ - capital adequacy ratio, $L D R$ - the loan-to-deposit ratio.

The significance test was performed for all variables using a $t$-test at a significance level of $95 \%$. The $p$-value of the selected variables if greater than 0.05 was considered to have a significant relationship with the dependent variable, i.e. return on assets (ROA) and return on equity (ROE), otherwise the relationship between the dependent and the independent variable will be considered unbrakeable. The significance test of the model was carried out by the calculation of the coefficient of correlation (r), the coefficient of determination $R^{2}$ and adjusted coefficient of determination $\left(\bar{R}^{2}\right)$. 


\subsection{Data collection}

The data were collected from the official websites of the Banking Agency of the Federation of Bosnia and Herzegovina and the Banking Agency of the Republika Srpska. This empirical study used quarterly data for the entire banking system of Bosnia and Herzegovina. The survey period covered the period from the first quarter of 2008 to the fourth quarter of 2019. In this research, STATA software was used in order to facilitate, support and provide answers to the study's questions and to test the research hypotheses.

The dependent variables, i.e. the return on assets (ROA) and the return on equity (ROE) were used. Seven independent variables were used, namely: the growth rate of net gross/loss (GRNGL), the growth rate of non-performing loans (GRNPL), the growth rate of the gross domestic product (GRGDP), the concentration ratio for the three to five banks in terms of loan placement (CR Loans), the concentration ratio for the three to five banks in terms of deposits (CR Deposits), capital adequacy ratio (CAR) and loan-to-deposit ratio (LDR). The data for the variables of commercial banks in Bosnia and Herzegovina were used to test the research hypotheses. Table 1 shows the explanatory variables and anticipated effects of dependent and independent variables.

Table 1. A brief description of the dependent and independent variables in the model

\begin{tabular}{|c|c|c|}
\hline Variable & Measured by & Anticipated signs \\
\hline ROE & This ratio is obtained by dividing the bank's net income with equity & - \\
\hline ROA & The ratio of profit to total assets & - \\
\hline GRNGL & The growth rate of net gross/loss & Positive (+) \\
\hline GRNPL & $\begin{array}{l}\text { The growth rate of non-performing loans (payment of interest and } \\
\text { principal past due date by } 90 \text { days or more) to total gross loans }\end{array}$ & Negative (-) \\
\hline GRGDP & The growth rate of the gross domestic product & Positive $(+)$ \\
\hline CR Loans & $\begin{array}{l}\text { The ratio of branch offices for the three to five banks to total bank } \\
\text { offices for all commercial banks. Therefore, the paper will test the } \\
\text { concentration ratio of three to five banks for loan placement }\end{array}$ & Positive $(+)$ \\
\hline CR Deposits & $\begin{array}{l}\text { The ratio of branch offices for the three to five banks to total bank } \\
\text { offices for all commercial banks. Therefore, the paper will test the } \\
\text { concentration ratio of three to five banks for deposits }\end{array}$ & Negative (-) \\
\hline CAR & Capital adequacy ratio & Negative $(-)$ \\
\hline LDR ratio & $\begin{array}{l}\text { The loan-to-deposit ratio is a measure of a bank's liquidity } \\
\text { assessment and is obtained as the ratio between total loans and total } \\
\text { deposits. }\end{array}$ & Negative $(-)$ \\
\hline
\end{tabular}

Source: author's own study.

Return on equity (ROE) expresses how much a bank earns on the book value of its investments. This ratio is obtained by dividing the bank's net income with equity, which reflects revenue generation, operational efficiency, financial leverage, and tax 
planning. For some banks ROE may be high because they do not have an adequate capital ratio. The capital adequacy ratio in Bosnia and Herzegovina is $12 \%$, which is the legal minimum so that almost all banks maintain a capital adequacy ratio. ROE can also be obtained as a product of ROA and the leverage multiplier, where a bank can use this ratio between two ratios to improve ROE ratios. For example, banks with low ROA can increase their ROE by using additional leverage, i.e. by increasing their asset-equity ratio (Koch and MacDonald, 2009).

Return on assets (ROA) is considered to be the most appropriate measure to evaluate the performance of a bank's business. ROA is obtained by dividing the bank's income before the interest is payable on its assets. Thus, ROA measures the effectiveness of management in using the resources of a bank to make a profit. It also evaluates the efficiency of the bank in using its financial and real investments to earn interest and other fees. This measure of bank profitability is particularly significant when comparing the operational efficiency between banks (Sinkey, 1988).

The growth rate of non-performing loans (NPLs) represents the sum of borrowed money by banks to debtors, where debtors have not made the payment of interest and principal at least 90 days for commercial bank loans and 180 days for consumer loans (Đukić, 2011).

The growth rate of the gross domestic product (GRGDP) is a measure of economic growth as it relates to gross domestic product from one period to another, adjusted for inflation, and presented in real terms as opposed to nominal. Vong and Chan (2009) argue that there is a general perception where the default values of bank loans are usually lower at a time of favourable economic growth, while they are higher during adverse economic growth, and these situations do affect the profit of banks. According to Ongore and Kusa (2013), the trend of gross domestic product influences bank's assets in the context that as trends move towards a declining GDP, demand for loans decreases, which negatively affects bank's profitability. Conversely, when economic trends move toward increasing magnitude or have positive GDP growth, then such a cycle leads to a high demand for credit.

Concentration ratio (CR) and the Herfindahl-Hirschman index are the main market concentration measures that have been proposed in many books and studies. The concentration ratio shows the share of the total market, especially in the banking market (for example, measured by employment, sales, assets, deposits, and loans). The banking sector of the Republika Srpska uses a concentration rate for the three largest banks in the system (Banking Agency of Republika Srpska, 2019), while the banking sector of the Federation of Bosnia and Herzegovina uses a concentration rate for the five largest banks in the system. This study took the average concentration ratio (Banking Agency of the Federation of Bosnia and Herzegovina, 2018).

The capital adequacy ratio (CAR) is the ratio determined by the regulatory body for supervising banking operations and serves to test the health of the banking system, i.e. it represents a safety device for the absorption of a certain amount of losses (Bokhari and Ali, 2009). 
The loan-to deposit ratio (LDR) is a measure of the banks' ability to refinance the eventual withdrawal of deposits that can be realized by savers relying on credit as a source of financing. If the ratio is high, the bank may face the problem of meeting unforeseen needs for funds; Conversely, if the ratio is too low, the bank will not earn as much as it could.

\subsection{Results}

The main results are shown in this section. Before the hypothesis is tested, primary statistic indicators' correlations are given in Tables 2 and 5. The total number of observations taken into consideration is 48 which represents a relatively representative sample both in terms of the company and the view of the timeframe.

Table 2. Descriptive statistics of dependent and independent variable variables of banks in Bosnia and Herzegovina in the period: 2008q1-2019q4

\begin{tabular}{|l|c|r|r|r|r|}
\hline \multicolumn{1}{|c|}{ Variables } & Obs & \multicolumn{1}{c|}{ Mean } & Std. Dev. & \multicolumn{1}{c|}{ Min } & \multicolumn{1}{c|}{ Max } \\
\hline ROE & 48 & 7,666 & 6,941 & $-8,53$ & 20,40 \\
\hline ROA & 48 & 0,514 & 0,459 & $-0,68$ & 1,30 \\
\hline GRNGL & 48 & 106,122 & 92,448 & $-124,29$ & 255,35 \\
\hline GRNPL & 48 & $1.590 .458,0$ & $822.698,40$ & 382,22 & 2.599 .508 \\
\hline GRGDP & 48 & $7.112 .134,0$ & $980.674,10$ & $539.820,40$ & $914.403,20$ \\
\hline CR Loans & 48 & 73,291 & 4,219 & 68,60 & 82,10 \\
\hline CR Deposits & 48 & 73,945 & 3,773 & 70,30 & 84,10 \\
\hline CAR & 48 & 16,345 & 0,835 & 14,90 & 18,0 \\
\hline LDR ratio & 48 & 90,645 & 5,891 & 78,59 & 99,74 \\
\hline
\end{tabular}

Source: calculated by the author.

The table above shows that the growth rate of GDP recorded higher volatility (980.674) than the growth rate of non-performing loans (822.698). GDP growth in the reporting period was recorded in $2007(6 \%)$, so that in 2009 the real GDP growth recorded a negative value of $2.7 \%$. In the period after 2009 there was a tendency of a further decline in GDP until 2013 as a result of weak economic activity and weak domestic and foreign demand. From 2014 to 2017 there was a slight improvement in economic activities measured by GDP as a reflection of economic recovery and increased exports. The growth rates of non-performing loans were also highly volatile. The highest value for the analyzed period was recorded in the third quarter of 2014 (about EUR 1.32 million), while the second lowest was recorded in the third quarter of 2019 (about EUR 801 thousand). The decrease was due to the monitoring of loans from banks, partial write-offs, and an increased volume of credit placements. It is important to mention that the movement of the first volatility measure, i.e. standard deviation and mean, had the same pattern of movement in the context of higher/ lesser volatility of the selected variables. 
Table 3. Correlation matrix between dependent and independent variables of banks in Bosnia and Herzegovina in the period: $2008 \mathrm{q} 1-2019 \mathrm{q} 4$

\begin{tabular}{|l|c|c|c|c|c|c|c|c|c|}
\hline \multicolumn{1}{|c|}{ Variables } & ROE & ROA & GRNGL & GRNPL & GRGDP & CRLoans & CRDeposits & CAR & $\begin{array}{c}\text { LDR } \\
\text { ratio }\end{array}$ \\
\hline ROE & 1.000 & & & & & & & & \\
\hline ROA & 0.979 & 1.000 & & & & & & & \\
\hline GRNGL & 0.957 & 0.947 & 1.000 & & & & & & \\
\hline GRNPL & -0.393 & -0.424 & -0.389 & 1.000 & & & & & \\
\hline GRGDP & 0.782 & 0.706 & 0.739 & 0.471 & 1.000 & & & & \\
\hline CRLoans & -0.664 & -0.641 & -0.636 & -0.814 & -0.752 & 1.000 & & & \\
\hline CRDeposits & -0.583 & -0.569 & -0.549 & -0.863 & -0.658 & 0.944 & 1.000 & & \\
\hline CAR & 0.179 & 0.157 & 0.203 & 0.193 & 0.184 & -0.193 & -0.194 & 1.000 & \\
\hline LDR ratio & -0.455 & -0.334 & -0.385 & -0.071 & -0.661 & 0.428 & 0.387 & 0.082 & 1.000 \\
\hline
\end{tabular}

Source: calculated by the authors.

The strongest positive causality with return on equity was achieved by the following independent variables: the return on assets (0.979), the growth rate of net gross/loss (0.957) and the growth rate of gross domestic product (0.782). A number of larger banks, even with a low return on assets (ROA), can achieve fairly high return on equity (ROE) with high borrowing or leverage and minimal capital utilization. With an increase in the rate of growth of net profit, the return on equity increases as net profit represents the basis for calculating the return. With an increase in business activity measured by the GDP growth rate, it also creates a favorable economic climate for foreign bank migration, which increases banking assets and lending placement, and thus influences the successful conversion of assets into bank earnings. The strongest negative correlation of the dependent variable return on equity (ROE) was recorded with the following independent variables: the concentration ratio of loans $(-0.664)$, the concentration ratio of deposits $(-0.583)$, the loan-to-deposit ratio $(-0.455)$ and the growth rate of non-performing loans $(-0.393)$. Therefore from three to five banks in the entire banking system of Bosnia and Herzegovina hold an oligopoly position which affects the increase of its profitability, but not the equal increase in the profitability of other banks in the system, and consequently has a slight decrease in the total return on assets. The relationship between loan-to-deposit ratio and return on equity is inverse because the relationship between liquidity and profitability is inversely proportional. For illustrative purposes, the share of liquid assets in the total assets in the banking sector of Bosnia and Herzegovina in 2007 amounted to a high $41.1 \%$, while in the third quarter of 2019 it dropped to about $26.2 \%$ (the Banking Agency of the Federation of Bosnia and Herzegovina and Herzegovina and Banking Agency of Republika Srpska, 2019). Such high amounts of liquid assets, especially in 2007, were primarily the result of the still present risk of credit placements, and the difficulty in finding good debtors and quality programs. 
The preceding VIF cutoffs were considered to be multi-collinear, which were set at industry level. Each variable that has a higher VIF than 3 was considered as multi-collinear and was dropped from the model. In the case of multi-collinearity, coefficients of the variables became unstable and standard errors were inflated.

Table 4. Multicolinear analysis via variance inflation factor (VIF)

\begin{tabular}{|l|c|c|}
\hline \multicolumn{1}{|c|}{ Variable } & VIF & 1/VIF \\
\hline GRNGL & 2.50 & 0.400430 \\
\hline GRNPL & 2.78 & 0.35971 \\
\hline GRGDP & 2.85 & 0.350877 \\
\hline CRLoans & 2.57 & 0.389105 \\
\hline CRDeposits & 2.69 & 0.371747 \\
\hline CAR & 1.14 & 0.877691 \\
\hline LDRratio & 2.87 & 0.348432 \\
\hline Mean VIF & 2.48 & \\
\hline
\end{tabular}

Source: calculated by the authors.

As seen in the above table, each individual independent variable has a value of VIF coefficient less than 3 , then it is clear that there is no multicollinearity between the variables and that the set model is valid.

\subsubsection{Results of testing the hypotheses}

Test of the first hypothesis

$\mathrm{H}_{0} \mathrm{I}$ ): There is no significant statistical impact of the factors (the growth rate of net gross/loss - GRNGL, the growth rate of non-performing loans - GRNPL, GDP growth rate-GRGDP, concentration ratio of loans of the largest banks in the system - CR Loans, concentration ratio of deposits of the largest banks in the system - CR Deposits, capital adequacy ratio - CAR and loan-to-deposit ratio - LDR) on the return on assets at $p \leq 0.05$.

Table 5 illustrates the results obtained using the multiple regression test. As can be seen, there is a significant impact of a number of independent variables on the dependent variable, i.e. on the ROA. Therefore, there is a significant correlation between the dependent and independent variables because the overall significance is less than 0.05. Additionally, there is no significant impact of the factors (concentration ratio of loans of the largest banks in the system, capital adequacy ratio and loan to deposit ratio). The value of the coefficient of correlation between ROA as a dependent variable and independent variables is $95.2 \%$. The obtained results lead to the conclusion, to the rejection of the null hypothesis and the acceptance of the alternative hypothesis. 
Table 5. Results of Multiple Linear Regression Tests between dependent and independent variables

\begin{tabular}{|c|r|l|}
\hline \multicolumn{2}{|c|}{ Independent variables } & \multicolumn{2}{c|}{ Name of independent variables } \\
\hline Sig & Coefficient & \multicolumn{1}{|c|}{} \\
\hline $\mathbf{0 . 0 0 1}$ & 0.005 & The growth rate of net gross/loss - GRNGL \\
\hline $\mathbf{0 . 0 0 4}$ & $-1.552 \mathrm{E}-8$ & The growth rate of non-performing loans - GRNPL \\
\hline $\mathbf{0 . 0 0 1}$ & $2.480 \mathrm{E}-8$ & GDP growth rate \\
\hline $\mathbf{0 . 8 3 7}$ & 0.004 & $\begin{array}{l}\text { The concentration ratio of loans of the largest banks in the } \\
\text { system - CR Loans }\end{array}$ \\
\hline $\mathbf{0 . 0 0 4}$ & -0.017 & $\begin{array}{l}\text { The concentration ratio of deposits of the largest banks in the } \\
\text { system - CR Deposits }\end{array}$ \\
\hline $\mathbf{0 . 2 4 8}$ & -0.033 & Capital adequacy ratio - CAR \\
\hline $\mathbf{0 . 2 2 4}$ & 0.065 & Loan to deposit ratio - LDR ratio \\
\hline \multicolumn{2}{|c|}{0.000} & \multicolumn{1}{c|}{ Sig. } \\
\hline \multicolumn{2}{|c|}{0.952} & $R^{2}$ \\
\hline
\end{tabular}

Source: calculated by the author.

$H_{0} I-1$ - There is no significant statistical impact of the growth rate of net gross/loss on the return on assets (ROA) at $p \leq 0.05$.

Table 6. Results of a Simple Linear Regression Test

\begin{tabular}{|c|c|c|}
\hline \multicolumn{2}{|c|}{ Independent variables } & \multirow{2}{*}{ Name of independent variable } \\
\hline Sig & Coefficient & $R^{2}$ \\
\hline $\mathbf{0 . 0 0 1}$ & 0.005 & The growth rate of net gross/loss - GRNGL \\
\hline \multicolumn{2}{|c|}{0.947} & \\
\hline
\end{tabular}

Source: author's own study.

By testing the first sub-hypothesis, the study concluded that there is a strong causality and a positive relationship between the growth rate of net gross/loss and ROA because the significance is less than 0.05 . The coefficient of correlation between these two variables recorded the high value of $94.7 \%$. The obtained results lead to the conclusion, to the rejection of the null hypothesis and the acceptance of the alternative hypothesis.

$\mathrm{H}_{0} \mathrm{I}-2$ - There is no significant statistical impact of growth rate of non-performing loans on the return on assets (ROA) at $p \leq 0.05$.

Table 7. Results of a Simple Linear Regression Test

\begin{tabular}{|c|c|c|}
\hline \multicolumn{2}{|c|}{ Independent variables } & \multirow{2}{*}{ Name of independent variable } \\
\hline Sig & Coefficient & $R^{2}$ \\
\hline $\mathbf{0 . 0 0 3}$ & $-2.37 \mathrm{e}-07$ & The growth rate of non-performing loans - GRNPL \\
\hline \multicolumn{2}{|c|}{0.424} & \\
\hline
\end{tabular}

Source: author's own study. 
To test the second sub-hypothesis a linear regression test was used. Therefore the results in Table 7 show that there is a significant impact of the growth rate of non-performing loans and ROA. This is because the value of significance is less than 5\%, and, the obtained coefficient f correlation amounted to $42.4 \%$. This result leads to the acceptance of the alternative hypothesis. Non-performing loans increased the cost of provisioning, and have the effect of reducing the bank's capital, making the bank unable to grow and expand its operations, and the result may be bank insolvency or liquidation (Babouček and Jančar, 2005). Banks with a high amount of non-performing loans in their investment portfolio are sure to achieve a reduction in their earnings (Bessis, 2006). In the banking sector of B\&H at the end of 2018, the share of non-performing loans in total loans amounted to only $6.5 \%$ as a result of permanent write-offs by individual banks. Reprogramming and better monitoring, as well as interest rate reductions, had a greater impact on reducing toxic loans (The Central Bank of Bosnia and Herzegovina, 2018, p. 35).

$\mathrm{H}_{0} \mathrm{I}-3$ - There is no significant statistical impact of growth rate of GDP growth rate on the return on assets (ROA) at $p \leq 0.05$.

Table 8. Results of a Simple Linear Regression Test

\begin{tabular}{|c|c|c|}
\hline \multicolumn{2}{|c|}{ Independent variables } & \multirow{2}{*}{ Name of independent variable } \\
\hline Sig & Coefficient & \\
\hline $\mathbf{0 . 0 0 1}$ & $3.31 \mathrm{e}-07$ & GDP growth rate \\
\hline \multicolumn{2}{|c|}{0.707} & $R^{2}$ \\
\hline
\end{tabular}

Source: calculated by the author.

To test the third sub-hypothesis, a linear regression test was used. The results in the previous table show that there is a significant relationship between return on assets (ROA) and GDP growth rate because the test significance value is less than $5 \%$. Additionally, the correlation coefficient is $70.7 \%$. Thus these results suggest the conclusion as the acceptance of the alternative hypothesis. The gross domestic product is one of the most common measures of economic activity in the country. The GDP growth has a significant positive impact on the profitability of the financial sector, such that if economic activity grows at a faster pace than defined, it requires a higher amount of loans and capital and higher credit placements, which in turn results in improved banking activity.

$\mathrm{H}_{0} \mathrm{I}-4$ - There is no significant statistical impact of concentration ratio of loans of the largest banks in the system on the return on assets (ROA) at $p \leq \mathbf{0 . 0 5}$. 
Table 9. Results of a Simple Linear Regression Test

\begin{tabular}{|c|c|c|}
\hline \multicolumn{2}{|c|}{ Independent variables } & \multicolumn{2}{c|}{ Name of independent variable } \\
\hline Sig & Coefficient & \multicolumn{1}{c|}{} \\
\hline $\mathbf{0 . 0 0 0}$ & -0.0697 & $\begin{array}{l}\text { The concentration ratio of loans of the largest banks } \\
\text { in the system - CR Loans }\end{array}$ \\
\hline \multicolumn{2}{|c|}{0.641} & $R^{2}$ \\
\hline
\end{tabular}

Source: calculated by the author.

To test the fourth sub-hypothesis, a linear regression test was used. Therefore the results in Table 9 shows that there is no significant impact of the concentration ratio of the loans for the largest banks in the system in the ROA because the value of significance is less than $5 \%$. The value of the coefficient of correlation is $64.1 \%$. This result leads to the acceptance of the alternative hypothesis.

$\mathrm{H}_{0} \mathrm{I}-5$ - There is no significant statistical impact of concentration ratio of deposits of the largest banks in the system on the return on assets (ROA) at $p \leq 0.05$.

Table 10. Results of a Simple Linear Regression Test

\begin{tabular}{|c|c|c|}
\hline \multicolumn{2}{|c|}{ Independent variables } & \multicolumn{2}{c|}{ Name of independent variable } \\
\cline { 1 - 2 } Sig & Coefficient & \multicolumn{1}{c|}{$\begin{array}{l}\text { The concentration ratio of deposits of the largest banks in the } \\
\text { system - CR Loans }\end{array}$} \\
\hline $\mathbf{0 . 0 0 3}$ & -0.0693 & $R^{2}$ \\
\hline \multicolumn{2}{|c|}{0.570} &
\end{tabular}

Source: calculated by the author.

To test the fifth sub-hypothesis, the author used a linear regression test. Therefore the results in Table 10 show that there is a significant impact of the concentration ratio of deposits for the largest banks in the system in the ROA, because the value of significance is less than $5 \%$. The value of the coefficient of correlation is $57.0 \%$. This result leads to the acceptance of the alternative hypothesis.

$\mathrm{H}_{0} \mathrm{I}-6$ - There is no significant statistical impact of capital adequacy ratio on the return on assets (ROA) at $p \leq 0.05$.

Table 11. Results of a Simple Linear Regression Test

\begin{tabular}{|c|c|c|}
\hline \multicolumn{2}{|c|}{ Independent variables } & Name of independent variable \\
\hline Sig & Coefficient & \\
\hline $\mathbf{0 . 2 8 7}$ & -0.086 & Capital adequacy ratio - CAR \\
\hline \multicolumn{2}{|c|}{0.157} & $R^{2}$ \\
\hline
\end{tabular}

Source: calculated by the author. 
To test the sixth sub-hypothesis, a linear regression test was used. Thus the results in Table 11 show that there is no significant impact of the capital adequacy ratio (CAR) in the ROA, because the value of significance is more than $5 \%$. The coefficient of correlation is also at a low level of only $15.70 \%$. This leads to the acceptance of the null hypothesis. According to the results, there is an inverse relationship between the dependent variable (ROA) and CAR. An increase in the capital adequacy rate of one unit, ceteris paribus, leads to a decrease of return on assets (ROA) by 0.08 units. Banks in Bosnia and Herzegovina had regulatory capital above $12 \%$ of the time horizon required by law. For the observed period, CAR recorded its highest value in the third and fourth quarters of 2019 , at $18 \%$ respectively. The lowest value was recorded in the third and fourth quarters of 2015, respectively, at $14.90 \%$ respectively.

$\mathrm{H}_{0} \mathrm{I}-7$ - There is no significant statistical impact of loans to deposit ratio on the return on assets (ROA) at $p \leq 0.05$.

Table 12. Results of a Simple Linear Regression Test

\begin{tabular}{|c|c|c|}
\hline \multicolumn{2}{|c|}{ Independent variables } & \multirow{2}{*}{ Name of independent variable } \\
\hline Sig & Coefficient & Loan to deposit ratio - LDR \\
\hline $\mathbf{0 . 0 7}$ & -0.0259 & $R^{2}$ \\
\hline \multicolumn{2}{|c|}{0.334} & \\
\hline
\end{tabular}

Source: author's own study.

To test the seventh sub-hypothesis, a linear regression test was used. Thus the results in Table 12 shows that there is no significant impact of the loan to deposit ratio (LDR) in the ROA, because the value of significance is more than 5\%, also the coefficient of correlation is $33.40 \%$. This result leads to the acceptance of the null hypothesis.

\section{Test of the second hypothesis}

$H_{0} \mathrm{II}$ ): There is no significant statistical impact of the factors (the growth rate of net gross/loss - GRNGL, the growth rate of non-performing loans - GRNPL, GDP growth rate-GRGDP, concentration ratio of loans of the largest banks in the system - CR Loans, concentration ratio of deposits of the largest banks in the system - CR Deposits, capital adequacy ratio-CAR and loan-to-deposit ratio) on the return on equity at $p \leq 0.05$.

Just as for testing the first hypothesis, to test the second hypothesis, the multiple regression test was used. The most significant influences on the dependent variable, i.e. return on equity, were recorded with the following independent variables (the growth rate of net gross/loss, the growth rate of non-performing loans, GDP growth rate and the concentration ratio of deposits of the largest banks in the system). The results of these variables showed good causality, since its value of the 
significance test is less than 0.05 . The obtained value of the coefficient of correlation is very high and achieved a value of $96.6 \%$. These lead to the conclusion of the annulment of the null hypothesis and the acceptance of the alternative hypothesis as to $6 \%$ of the change on return on equity (Table 13 ).

Table 13. Results of Multiple Linear Regression Tests between dependent and independent variables

\begin{tabular}{|c|c|l|}
\hline \multicolumn{2}{|c|}{ Independent variables } & \multicolumn{2}{|}{ Name of independent variables } \\
\cline { 1 - 2 } Sig & Coefficient & \\
\cline { 1 - 2 } $\mathbf{0 . 0 0 1}$ & 0.0625 & The growth rate of net gross/loss - GRNGL \\
\hline $\mathbf{0 . 0 0 6}$ & $-7.84 \mathrm{e}-07$ & The growth rate of non-performing loans - GRNPL \\
\hline $\mathbf{0 . 0 0 1}$ & $9.38 \mathrm{e}-07$ & GDP growth rate \\
\hline $\mathbf{0 . 0 0 4}$ & -0.02387 & $\begin{array}{l}\text { The concentration ratio of loans of the largest banks in the } \\
\text { system }- \text { CR Loans }\end{array}$ \\
\hline $\mathbf{0 . 0 0 3}$ & -0.2443 & $\begin{array}{l}\text { The concentration ratio of deposits of the largest banks in the } \\
\text { system }- \text { CR Deposits }\end{array}$ \\
\hline $\mathbf{0 . 6 7 1}$ & -0.1560 & Capital adequacy ratio - CAR \\
\hline
\end{tabular}

Source: calculated by the author.

\section{$\mathrm{H}_{0} \mathrm{II}$ - 1 - There is no significant statistical impact of the growth rate of net gross/loss on the return on equity (ROE) at $p \leq 0.05$.}

Table 14. Results of a Simple Linear Regression Test

\begin{tabular}{|c|c|c|}
\hline \multicolumn{2}{|c|}{ Independent variables } & Name of independent variable \\
\hline Sig & Coefficient & The growth rate of net gross/loss - GRNGL \\
\hline $\mathbf{0 . 0 0 1}$ & 0.0718 & $R^{2}$ \\
\hline \multicolumn{2}{|c|}{0.957} & \\
\hline
\end{tabular}

Source: calculated by the author.

By testing the second sub-hypothesis, the author came to the conclusion that there is a strong causality and a positive relationship between the growth rate of net gross/loss and ROE because the significance is less than 0.05 . The coefficient of correlation between these two variables recorded a high value of $95.7 \%$. The obtained results lead to the conclusion to the rejection of the null hypothesis and the acceptance of the alternative hypothesis. 
$\mathrm{H}_{0} \mathrm{II}$ - 2 - There is no significant statistical impact of growth rate of non-performing loans on the return on equity (ROE) at $p \leq 0.05$.

Table 15. Results of a Simple Linear Regression Test

\begin{tabular}{|c|c|c|}
\hline \multicolumn{2}{|c|}{ Independent variables } & Name of independent variable \\
\hline Sig & Coefficient & The growth rate of non-performing loans - GRNPL \\
\hline $\mathbf{0 . 0 0 6}$ & $3.32 \mathrm{e}-06$ & $R^{2}$ \\
\hline \multicolumn{2}{|c|}{0.393} & \\
\hline
\end{tabular}

Source: calculated by the author.

To test the second sub hypothesis, the study also used a linear regression test. Thus the results in Table 15 shows that there is no significant impact of the growth rate of non-performing loans (GRNPL) in the ROE, because the value of significance is more than $5 \%$, while the coefficient of correlation is $39.30 \%$. This result leads to the acceptance of the null hypothesis.

$\mathrm{H}_{0} \mathrm{II}-3$ - There is no significant statistical impact of growth rate of GDP growth rate on the return on equity (ROE) at $p \leq 0.05$.

Table 16. Results of a Simple Linear Regression Test

\begin{tabular}{|c|c|l|}
\hline \multicolumn{2}{|c|}{ Independent variables } & \multicolumn{2}{c|}{ Name of independent variable } \\
\hline Sig & Coefficient & \multicolumn{2}{|c|}{$R^{2}$} \\
\hline $\mathbf{0 . 0 0 0}$ & $5.54 \mathrm{e}-06$ & GDP growth rate \\
\hline \multicolumn{2}{|c|}{0.782} & \\
\hline
\end{tabular}

Source: calculated by the author.

To test the third sub-hypothesis, a linear regression test was used. The results in the above table show that there is a significant relationship between return on equity (ROE) and GDP growth rate because the test significance value is less than 5\%. Additionally, the correlation coefficient is $78.20 \%$. Thus, these results suggest the conclusion as to the acceptance of the alternative hypothesis.

$\mathrm{H}_{0} \mathrm{II}-4$ - There is no significant statistical impact of concentration ratio of loans of the largest banks in the system on the return on equity (ROE) at $p \leq 0.05$.

Table 17. Results of a Simple Linear Regression Test

\begin{tabular}{|c|c|c|}
\hline \multicolumn{2}{|c|}{ Independent variables } & \multicolumn{2}{c|}{ Name of independent variable } \\
\hline Sig & Coefficient & \\
\hline $\mathbf{0 . 0 0 1}$ & -1.0923 & The concentration ratio of loans of the largest banks in the system \\
\hline \multicolumn{2}{|c|}{0.664} & $R^{2}$ \\
\hline
\end{tabular}

Source: calculated by the author. 
To test the fourth sub-hypothesis, a linear regression test was used. Therefore the results in Table 17 show that there is significant impact of the concentration ratio of loans in the largest banks in the system in the ROE, because the value of significance is less than $5 \%$. The value of the coefficient of correlation is $66.4 \%$. This result leads to the acceptance of the alternative hypothesis. In the banking sector in the Federation of Bosnia and Herzegovina, mainly four banks have a dominant market share, as well as their dominant share in the financial result. This shows that in the structure of the total positive results of banks in the B\&H at the end of 2019, the most dominant share was for the following banks: Unicredit bank in Mostar (36.90\%), Raiffeisen Bank Sarajevo (20.77\%), then Intesa Sanpaolo Bosnia and Herzegovina (12.38\%) and Sparkasse bank Bosnia and Herzegovina (8.57\%).Therefore the banking market in Bosnia and Herzegovina has an oligopolistic situation, where with increasing concentration there is a growing trend in terms of the financial results of the first four banks, while the other banks have a much smaller structural share in the overall financial results.

$\mathrm{H}_{0} \mathrm{II}-5$ - There is no significant statistical impact of concentration ratio of deposits of the largest banks in the system on the return on equity (ROE) at $p \leq \mathbf{0 . 0 5}$.

Table 18. Results of a Simple Linear Regression Test

\begin{tabular}{|c|c|c|}
\hline \multicolumn{2}{|c|}{ Independent variables } & \multirow{2}{*}{ Name of independent variable } \\
\cline { 1 - 2 } Sig & Coefficient & \\
\hline $\mathbf{0 . 0 0 4}$ & -1.0727 & The concentration ratio of deposits of the largest banks in the system \\
\hline \multicolumn{2}{|c|}{0.583} & $R^{2}$ \\
\hline
\end{tabular}

Source: calculated by the author.

To test the fifth sub-hypothesis, a linear regression test was used. Therefore the results in Table 18 show that there is significant impact of the concentration ratio of deposits in the largest banks in the system in the ROE, because the value of significance is less than $5 \%$. The value of the coefficient of correlation is $58.3 \%$. This leads to the acceptance of the alternative hypothesis.

$\mathrm{H}_{0} \mathrm{II}-6$ - There is no significant statistical impact of capital adequacy ratio on the return on equity (ROE) at $p \leq 0.05$.

Table 19. Results of a Simple Linear Regression Test

\begin{tabular}{|c|c|c|}
\hline \multicolumn{2}{|c|}{ Independent variables } & \multirow{2}{*}{ Name of independent variable } \\
\hline Sig & Coefficient & \\
\hline 0.223 & 1.4888 & Capital adequacy ratio - CAR \\
\hline \multicolumn{2}{|c|}{0.179} & $R^{2}$ \\
\hline
\end{tabular}

Source: calculated by the author. 
To test the sixth sub hypothesis, a linear regression test was used. Thus the results in Table 19 show that there is no significant impact of the capital adequacy ratio (CAR) in the ROE, because the value of significance is more than $5 \%$, and the coefficient of correlation is at a low level of only $17.90 \%$. This leads to the acceptance of the null hypothesis. According to Flannery and Rangan (2008), banks with low capital and higher levels of risk can increase profits by increasing the equity multiplier. However, banks in B\&H maintain a legal minimum of $12 \%$ and higher at all times in order to preserve their financial stability and respect the regulatory framework.

\section{$\mathrm{H}_{0} \mathrm{I}-7$ - There is no significant statistical impact of loans to deposit ratio on the return on equity (ROE) at $p \leq 0.05$.}

Table 20. Results of a Simple Linear Regression Test

\begin{tabular}{|c|c|c|}
\hline \multicolumn{2}{|c|}{ Independent variables } & \multicolumn{2}{c|}{ Name of independent variable } \\
\cline { 1 - 2 } Sig & Coefficient & \\
\hline $\mathbf{0 . 0 6}$ & -0.536 & Loans to deposit ratio \\
\hline \multicolumn{2}{|c|}{0.455} & $R^{2}$ \\
\hline
\end{tabular}

Source: calculated by the author.

To test the seventh sub-hypothesis, a linear regression test was used. Therefore the results in Table 20 show that there is no significant impact of the loan to deposit ratio (LDR) in the ROE, because the value of significance is more than $5 \%$, while the coefficient of correlation is $45.50 \%$. This leads to the acceptance of the null hypothesis.

\section{Conclusion}

Bank profitability is a very important determinant of both the banks and the entire financial system. Further lending to the economy depends on bank profitability. In this regard, bank profitability depends primarily on the amount of lending and credit risk associated with the lending, as well as other risks arising from the macroeconomic environment.

In this research, an attempt was made to determine which internal and which external factors have an impact on the profitability of banks in Bosnia and Herzegovina as measured by return on assets and return on equity period of q1 2008 to q4 2019 in the research part of the paper through the underlying correlation analysis and regression analysis with the use of $t$-test and at a level of significance of $95 \%$ in order to test the hypotheses. Therefore the findings of the study indicated that within the first hypothesis was confirmed the following sub-hypotheses: the first, the second, the third, the fourth, the fifth and the seventh. The sixth sub-hypothesis 
was rejected. Therefore the strongest impact on the dependent variable, i.e. return on assets (ROA) was recorded by the following independent variables: the growth rate of net gross/loss, GDP growth rate, the growth rate of non-performing loans and the concentration ratio of loans of the largest banks in the system. However, the following two variables had the weakest impact on ROA: capital adequacy ratio and loan to deposit ratio. Within the second hypothesis, the following sub-hypotheses were confirmed: the first, the third, the fourth, and the fifth. The second, sixth and seventh hypotheses were rejected. The strongest impact on the dependent variable, i.e. return on equity (ROE) was achieved by the following independent variables: the growth rate of net gross/loss, GDP growth rate, the concentration ratio of loans of the largest banks in the system and the concentration ratio of deposits of the largest banks in the system. However, the most significant negative link on the dependent variables were the return on equity (ROE) achieved by the following independent variables: capital adequacy ratio, loan to deposit ratio and growth rate of non-performing loans.

Improving the performance of banks in Bosnia and Herzegovina over the next few years will be a major challenge due to the influence of external factors such as slower economic growth, increased competitiveness, the saturation of economy and population with credit, slow growth of employment and income, etc. In this regard, a successful response to a turbulent environment is certainly to forecast the bank's performance. Therefore a larger data set of $\mathrm{B} \& \mathrm{H}$ banks could help to incorporate more determinants into the model and provide better understanding of the long-term and short-term relationships to the bank's profitability. This issue should be further explored.

\section{References}

Babouček, I., and Jančar, M. (2005). Effects of macroeconomic shock to the quality of the aggregate loan portfolio (Working Paper Series No. 1). Czech National Bank, 1-62.

Banking Agency of Republika Srpska. (2018). Report on Condition of the Banking System of Republika Srpska. Retrieved from https://abrs.ba/public/data/documents/1245/ReportBankingSystem31122018.pdf

Banking Agency of the Federation of Bosnia and Herzegovina. (2018). Information on the Banking System Entities of the Federation of Bosnia and Herzegovina. Retrieved from https://www.fba.ba/ upload/docs/informacija_o_subjektima_bankarskog_sistema_31122018_eng_5_tXo.pdf

Banking Agency of the Federation of Bosnia and Herzegovina. (2019). Information on the Banking System Entities of the Federation of Bosnia and Herzegovina. Retrieved from https://www.fba.ba/ upload/docs/informacija_o_bankarskom_sistemu_30092019_eng_fra.pdf

Bessis, J. (2006). Risk management in banking. London: John Wiley \& Sons Ltd.

Bikker, J. A., and Bos, J. W. B. (2008). Bank performance: A theoretical and empirical framework for the analysis of profitability, competition and efficiency. New York: Routledge.

Bokhari, I. H., and Ali, S. M. (2009). Determinants of capital adequacy ratio in banking sector: An empirical analysis from Pakistan. Academy of Contemporary Research Journal, 1(1), 1-9.

Borio, C., Gambacorta, L., and Hofmann, B. (2015). The influence of monetary policy on bank profitability (BIS Working Papers No. 514), October. 
Boubakri, N., Cosset, J., Fischer, K., and Guedhami, O. (2005). Privatization and bank performance in developing countries. Journal of Banking and Finance, 29, 2015-2041.

Bordeleau, É., and Graham, C. (2010). The impact of liquidity on bank profitability (Working Paper/ Document de travail).

Căpraru, B., and Ihnatov, I. (2015). Determinants of bank's profitability in the EU15. Scientific Annals of the AlexandruIoanCuza, 62(1), 93-101.

Ćuraka, M., Poposkib, K., and Pepura, S. (2012). Profitability determinants of the Macedonian banking sector in changing environment. Procedia-Social and Behavioral Sciences, 44, 406-416.

Dietrich, A., and Wanzenried, G. (2011). Determinants of bank profitability before and during the crisis: Evidence from Switzerland. Journal of International Financial Markets, Institutions and Money, 21(3), 307-327.

Đukić, Đ. (2011). Upravljanje rizicima i kapitalom u bankama. Beograd: Centar za izdavačku delatnost Ekonomskog fakulteta u Beogradu.

Flannery, M. J., and Rangan, K. P. (2008). What caused the bank capital build-up of the 1990s?, Review of Finance, 12, 391-429.

Goddard, J., Molyneux, P., and Wilson, J. (2004). Dynamics of growth and profitability in banking, Journal of Money, Credit and Banking, 36(3), 1069-1090.

Gorton, F., and Winton, A. (2005). Financial intermediation. Harrysburg, PA: University of Pennsylvania Press.

Gul, S., Irshad, F., and Zaman, K. (2011). Factors affecting bank profitability in Pakistan. The Romanian Economic Journal, 39, 61-87.

Ibrahimov, A. (2016). The impact of devaluation and oil price on the banking sector of Azerbaijan (Master's dissertation). Porto University, Porto, Portugal, July. Retrieved April 12, 2020 from https://sigarra.up.pt/fep/pt/pub_geral.show_file?pi_gdoc_id=779998

Koch, T. W., and MacDonald, S. S. (2009). Bank management. Cengage Learning.

Kosmidou, K. (2008). The determinants of banks' profits in Greece during the period of EU financial integration. Managerial Finance, 34(3), 146-159.

Mishkin, F. S. (2007). The economics of money, banking, and financial markets (eight edition). The Addison-Wesley Series in Economics.

Naceur, S. B., and Omran, M.(2011). The effects of bank regulations, competition, and financial reforms on banks' performance. Emerging Markets Review, 12, 1-20.

Ongore, V. O., and Kusa, G. B. (2013). Determinants of financial performance of commercial banks in Kenya. International Journal of Economics and Financial Issues, 3(1), 237-252.

Satria, I., Supriyadi, E., Irfani, A., and Djamil, A. (2018). The most important factors affecting profitability of the top 10 commercial banks in Asean. The International Journal of Social Sciences and Humanities Invention, 5(05), 4742-4753.

Sinkey, J. F. (1998). Commercial bank financial management. New York, London: Macmillan.

The Central Bank of Bosnia and Herzegovina. (2018). Financial Stability Report. Retrieved from https://www.cbbh.ba/Content/Archive/575?lang=bs

Trujillo-Ponce, A. (2013). What determines the profitability of banks? Evidence from Spain. Journal of Accounting and Finance, 53, 561-586.

Vong, A. P. I., and Chan, H. S. (2009). Determinants of bank profitability in Macao (Working Paper Series), University of Macau, 93-113. 


\section{CZYNNIKI WPLYWAJĄCE NA RENTOWNOŚĆ BANKÓW: PRZYPADEK BOŚNI I HERCEGOWINY}

Streszczenie: Badaniem objęto wszystkie banki funkcjonujące w Bośni i Hercegowinie. Głównym jego celem jest określenie znaczenia zewnętrznych i wewnętrznych zmiennych dotyczących rentowności banków. Podstawą analizy są dane pochodzące z raportów kwartalnych Agencji Bankowej Federacji B\&H i Agencji Bankowej Republiki Serbskiej za lata 2008-2019. Do analizy korelacji i regresji wykorzystano następujące zmienne zależne: ROA i ROE oraz zmienne niezależne: GRNGL, GRNPL, GRGDP, wskaźnik koncentracji kredytów największych banków w systemie (pożyczki CR), wskaźnik koncentracji depozytów największych banków w systemie (depozyty CR), CAR i wskaźnik zdolności kredytowej do depozytu. Badanie wykazało istotny wpływ statystycznych zmiennych na ROA i ROE. Dodatkowo wskazano na potrzebę właściwego wyboru dłużników przez banki oraz kontroli kosztów, toksycznych pożyczek i rezerw w celu zwiększenia zysków i obniżenia kosztów.

Słowa kluczowe: wskaźniki rentowności, kredyty zagrożone, wskaźnik koncentracji, stosunek kredytów do depozytów. 